\title{
ANALISIS DETERMINAN TINGKAT PROPORSI DANA TABARRU' PADA ASURANSI JIWA SYARIAH
}

\author{
Nuraini dan Mustafa Kamal \\ Sekolah Tinggi Ekonomi Islam SEBI \\ Email:nuraini.nuni96@gmail.com \\ DOI: https://doi.org/10.5281/jakis.v6i2.11
}

\begin{abstract}
This research aims to determine influence of the claim risk, retakaful contribution, operating expenses, exchange rate, inflation rate and BI rate toward proportion of tabarru' funds on Islamic life insurance companies. Sampling is done by purposive sampling technique to get 138 data from different starting ranges data and periods, with the final sample of 23 Islamic life insurance companies during 2010-2017. The method of analysis used in this research is multiple linear regression using unbalanced panel data that processed by using Eviews 9. The result showed that the best estimation model for this research is Random Effect Model (REM). Simultaneously all of the independent variables have significant influence towards proportion of tabarru' funds. While partially, claim risk has positive significant, retakaful contribution and operating expenses has negative significant influence towards proportion of tabarru' funds. As for the macroeconomic variables, namely exchange rate, inflation rate and $\mathrm{BI}$ rate have no significant influence towards proportion of tabarru' funds.
\end{abstract}

$\begin{array}{ll}\text { Keyword: } & \text { Proportion Of Tabarru' Funds, Islamic Life Insurance, Claim } \\ & \text { Risk, Contribution Retakaful, Operating Expenses, } \\ & \text { Macroeconomic }\end{array}$

\section{PENDAHULUAN}

Laporan Perkembangan Keuangan Syariah, OJK (2017), mengungkapkan bahwa, industri asuransi syariah mengalami perkembangan yang cukup dinamis, termasuk perkembangan praktik bisnis yang dilakukan oleh pelaku usaha asuransi syariah. Hal itu ditandai dengan kemampuannya menduduki posisi kedua setelah perbankan syariah. Meskipun pangsa pasar asuransi syariah saat ini baru mencapai 4,7\% (Republika, 2017).Statistik IKNB Syariah, OJK (2017), menunjukkan bahwa jumlah asuransi syariah di Indonesia telah bertambah menjadi 63 industri. Dengan adanya peraturan pemerintah mengenai modal minimum asuransi, serta rencana beberapa perusahaan asuransi syariah melakukan spin off sesuai peraturan undangundang tentang perasuransian, maka dapat diprediksikan bahwa hingga tahun-tahun kedepan jumlah asuransi syariah akan terus bertambah (Karim Consulting Indonesia, 2016).

Namun demikian, berdasarkan data OJK 2017 tercatat bahwa 83\% pertumbuhan aset asuransi syariah dikuasai oleh perusahaan asuransi jiwa syariah. Tingginya nilai aset asuransi jiwa syariah tersebut menunjukkan, 
bahwa pertumbuhan asuransi jiwa syariah pun sangat baik dibandingkan dengan industri asuransi syariah lainnya. Pertumbuhan tersebut pun memiliki dampak yang positif pada perekonomian negara. Sebagaimana yang diungkapkan oleh Hamizun (2013), bahwa takaful (asuransi syariah) memiliki potensi untuk memainkan peran penting dalam memberikan kontribusi terhadap pertumbuhan ekonomi.

Atas dasar itulah diberlakukan regulasi yang mengikat terkait praktek industri asuransi syariah. Salah satunya yaitu Fatwa Dewan Syariah Nasional, (2001) No 21 tentang Pedoman Umum Asuransi Syariah, yang menekankan pada konsep dasar asuransi syariah itu sendiri yaitu usaha saling melindungi dan tolong-menolong diantara sejumlah orang/pihak melalui investasi dalam bentuk dana tabarru'/dana kontribusi peserta. Dimana perusahaan hanya berperan sebagai wakil atau pengelola atas danatabarru' tersebut.

Konsep dasar tersebut menyimpulkan bahwa sumber dana bisnis asuransi syariah adalah dari dana tabarru' atau dana kontribusi yang dihimpun dari peserta. Oleh karena itu, peran strategi manajemen keuangan menjadi penting dalam pengaturan aset dan liabilitas, serta mengetahui pengaruhnya terhadap risk, return, dan performance sejak dari awal mendapatkan amanah untuk mengelola dana kontribusi peserta tersebut (Puspitasari, 2011, hlm. 129).

Iuran dana kontribusiyang dibayar peserta asuransi jiwa syariah merupakan dana yang terdiri atas tiga komponen, yaitu dana tabarru', investasi peserta, dan fee (ujroh) pengelola. Sebagaimana menurut Bayinah, et al (2017, hlm. 94) kontribusi pada asuransi jiwa syariah dengan produk tabungan (saving), merupakan transaksi untuk dana peserta yang mencakup dana tabarru', dana fee (ujroh) yang dibayarkan untuk pengelola, serta dana tabungan atau dana investasi. Sehingga dari setiap dana tersebut memiliki kolom kelompok tersendiri sesuai dengan akad dan peruntukannya.

Selain itu, didukung pula oleh regulasi lainnya yaitu PMK Nomor 18/PMK.010/2010, terkhusus di BAB III yang penekanannya pada operator atau perusahaan asuransi syariah harus melakukan pemisahan kekayaan dan kewajiban danatabarru' dari kewajiban dan kekayaan dana perusahaan. Oleh sebab itu perlakuan akuntansi ketika menerima kontribusi peserta diawal sejalan dengan konsep Fund Theory yaitu konsep yang penekanannya pada arus dana dan penggunaannya (Harahap, 2008, hlm. 176).

Manajemen dalam melakukan pemisahaan dana kontribusi peserta dalam praktiknya membutuhkan sebuah proporsi. Dalam mekanismenya, kontribusi yang dibayarkan peserta dibagi dalam dua rekening, yaitu rekening peserta dan rekening tabarru'. Pada rekening tabarru' inilah ditampung semua dana tabarru' peserta sebagai dana tolong-menolong atau dana kebajikan, yang jumlahnya sekitar 5\%-10\% dari premi pertama (Sula, 2004, hlm. 175).

Namun demikian, hingga saat belum adanya regulasi standar yang mengatur masalah pembagian proporsi atas dana kontribusi peserta tersebut (Puspitasari, 2012, hlm. 45). Fenomena yang terjadi dilapangan terdapat 
perbedaan besaran proporsi dana kontribusi peserta untuk kolom akun dana tabarru' dan ujrah di setiap perusahaan asuransi jiwa syariah.

Berikut ini menunjukkan perbandingan proporsi dana tabarru' dan ujrah (fee)perusahaan dari total dana kontribusinya selama periode 20142016.

Tabel 1. Proporsi Dana Tabarru' dan Ujrah Perusahaan atas Total Dana Kontribusi Peserta

\begin{tabular}{lcccc}
\hline \multicolumn{1}{c}{$\begin{array}{c}\text { Nama } \\
\text { Perusahaan }\end{array}$} & Tahun & $\begin{array}{c}\text { Proporsi } \\
\text { Ujroh }\end{array}$ & $\begin{array}{c}\text { Proporsi Dana } \\
\text { Tabarru' }\end{array}$ & other \\
\hline PT Asuransi & 2014 & $46 \%$ & $41 \%$ & $12 \%$ \\
Takaful & 2015 & $46 \%$ & $39 \%$ & $15 \%$ \\
Keluarga & 2016 & $48 \%$ & $33 \%$ & $19 \%$ \\
\hline PT Asuransi & 2014 & $30 \%$ & $27 \%$ & $43 \%$ \\
\cline { 2 - 5 } Jiwa Al Amin & 2015 & $24 \%$ & $42 \%$ & $33 \%$ \\
\cline { 2 - 5 } & 2016 & $20 \%$ & $32 \%$ & $48 \%$ \\
\hline PT AJS Amanah & 2014 & $31 \%$ & $32 \%$ & $37 \%$ \\
\cline { 2 - 5 } Jiwa Giri Artha & 2015 & $45 \%$ & $10 \%$ & $46 \%$ \\
\cline { 2 - 5 } & 2016 & $34 \%$ & $32 \%$ & $33 \%$ \\
\hline \multirow{3}{*}{ PT IAI Financial } & 2014 & $92 \%$ & $7 \%$ & $1 \%$ \\
\cline { 2 - 5 } & 2015 & $90 \%$ & $8 \%$ & $3 \%$ \\
\hline PT Asuransi & 2016 & $90 \%$ & $8 \%$ & $2 \%$ \\
Allianz Life & 2014 & $62 \%$ & $31 \%$ & $7 \%$ \\
Indonesia & 2016 & $60 \%$ & $33 \%$ & $7 \%$ \\
\hline PT AXA & 2014 & $52 \%$ & $35 \%$ & $17 \%$ \\
Financial & 2015 & $52 \%$ & $32 \%$ & $17 \%$ \\
Indonesia & 2016 & $52 \%$ & $32 \%$ \\
\hline
\end{tabular}

Sumber: Data diolah dari Laporan Keuangan Tahunan Perusahaan (2014;2016)

Tabel diatas menunjukkan bahwa proporsi danatabarru' dari total dana kontribusi peserta pada setiap perusahaan dan tiap tahunnya memiliki komposisi nilai yang berbeda. Menurut Purwocaroko \& Suprayogi (2016), jika komposisi dana tabarru' dengan dana ujrah tidak dalam posisi yang baik dan ideal, maka hal tersebut akan berpengaruh pada kondisi kepemilikan masing-masing aset tersebut dan kinerja keuangan perusahaan asuransi syariah.

Perbedaan proporsi ini disamping tidak adanya standar yang mengatur juga dipengaruhi oleh beberapa faktor. Oleh karena itu, memahami faktorfaktor yang dapat mempengaruhi tingkat proporsi danatabarru' menjadi penting agar dapat membantu manajemen dalam pengambilan keputusan.

Penelitian dengan tema sejenis pertama kali dilakukan oleh Puspitasari (2011) yang mengungkapkan bahwa, faktor utama penentuan proporsi dana tabarru' ialah klaim dan retakaful. Puspitasari kembali melakukan pengembangan penelitiannya di tahun 2012 \& 2016, dimana temuan 
penelitiannya mengungkapkan bahwa variabel risiko klaim, kegiatan retakaful, biaya komisi, dan beban administrasi umum berpengaruh secara signifikan terhadap penentuan proporsi dana tabarru' pada asuransi umum syariah. Adapun pada perusahaan asuransi jiwa syariah, penelitian sejenis dilakukan oleh Puwocaroko \& Suprayogi (2016) yang mengungkapkan bahwa, faktor utama penentuan proporsi dana tabarru' ialah klaim dan retakaful.

Penelitian empiris mengenai faktor-faktor yang mempengaruhi tingkat proporsi danatabarru' pada perusahaan asuransi jiwa syariah masih sangat terbatas, belum banyak dilakukan diberbagai negara. Sehingga, untuk pengembangan penelitian ini, penulis mengasumsikan bahwa konsep dasar faktor-faktor proporsi danatabarru' sama dengan penentuan faktor-faktor nisbah bagi hasil di bank syariah. Dimana istilah nisbah bagi hasil pada bank syariah merupakan istilah yang digunakan dalam proporsi bagi hasil antara nasabah dan bank syariah (Ifham, 2015, hlm. 47). Istilah tersebutpun memiliki arti yang sama pada proporsi dana tabarru' atas dana kontribusi antara peserta dengan perusahaan asuransi syariah.

Sebagaimana telah banyak penelitian yang dilakukan terkait faktor yang mempengaruhi tingkat bagi hasil di bank syariah, diantaranya oleh Hidayat \& Rahman (2015), Yuksel, Canoz, \& Ozsari, (2017), Romansyah (2009), Kunti \& Sunaryo (2012), Affandi (2016), Arif (2011), serta Arfiani \& Mulazid (2017)yang mengungkapkan bahwa variabel makroekonomi seperti tingkat BI-Rate, inflasi, dan nilai tukar rupiah memiliki pengaruh signifikan terhadap tingkat bagi hasil di bank syariah.Temuan penelitian tersebut menjadi acuan konsep dasar sejenis untuk mengetahui pengaruhnya terhadap penetapan tingkat proporsi danatabarru' di asuransi jiwa syariah.

Berdasarkan beberapa penelitian diatas, maka dapat diambil hipotesis bahwa risiko klaim, kontribusi retakaful, beban operasional, nilai tukar rupiah, inflasi dan BI-Rate dapat mempengaruhi manajemen dalam menetapkan tingkat proporsi danatabarru' pada perusahaan asuransi jiwa syariah di Indonesia.

Tingkat proporsi danatabarru' perusahaan atas dana kontribusi peserta menjadi suatu bahasan yang menarik untuk dikaji guna memberikan informasi yang bermanfaat bagi perusahaan asuransi jiwa syariah khususnya. Dimana penelitian ini merupakan penelitian pertama yang mengulas faktor tingkat proporsi danatabarru' pada perusahaan asuransi jiwa syariah di Indonesia. Disamping itu, diharapkan dapat menjadi tambahan referensi baru pada kajian manajemen keuangan asuransi syariah yang sampai saat ini masih sangat terbatas. Kajian manajemen keuangan syariah pada penelitianpenelitian empiris lebih banyak membahas pada manajemen keuangan perbankan syariah. 


\section{TELAAH TEORITIS DAN PENGEMBANGAN HIPOTESIS}

\subsection{RISIKO KLAIM}

Klaim adalah nilai pertanggungan yang diberikan ke peserta atas kerugian yang dialaminya. Dalam perusahaan asuransi syariah, klaim bukan merupakan beban pengelola tetapi merupakan beban asuransi atau underwriting yang diambil dari dana peserta. Perbedaan ini disebabkan oleh konsep dana tabarru' dan pembagian risiko (sharing of risk) yang digunakan oleh perusahaan asuransi syariah (Bayinah et al., 2017, hlm. 107).

Menurut Sula, (2004, hlm. 259), klaim adalah aplikasi oleh peserta untuk memperoleh pertanggungan atas kerugiannya yang tersedia berdasarkan perjanjian. Melalui klaim tersebut peserta dapat memperoleh hak-hak berdasarkan perjanjian tersebut. Semua usaha yang diberikan untuk menjamin hak-hak tersebut dihormati sepenuhnya sebagaimana yang seharusnya. Oleh karena itu, penting bagi pengelola asuransi syariah untuk mengatasi klaim secara efisien.

Untuk mengatasi keuangan klaim, maka perusahaan asuransi syariah pada umumnya akan mengelola risiko klaim dengan melakukan penyisihan dana atau biasa dikenal dengan sebutan penyisihan teknik (technical provision). Penyisihan teknik ini dalam asuransi syariah telah diatur dalam PSAK No.108 tentang Akuntansi Transaksi Asuransi Syariah refisi efektif 1 Januari 2017. Penyisihan teknik tersebut terdiri atas 4 kelompok. Keempat jenis penyisihan teknik tersebut merupakan kelompok penambah nilai risiko klaim, disajikan dalam laporan keuangan surplus underwriting dana peserta yang termasuk sebagai beban asuransi.

Puspitsari (2011) menemukan bahwa jika klaim semakin tinggi, maka proporsi tabarru' yang dibutuhkan mengalami peningkatan. Sebaliknya, semakin rendah klaim, proporsi danatabarru' juga akan rendah. Jika tabarru' tidak ditingkatkan atau diperbesar, maka perusahaan asuransi Syariah akan berpeluang untuk mengeluarkn qardhul hasan.

Oleh karena itu, berdasarkan teori dan penelitian sebelumnya yang telah diuraikan, dapat disusun hipotesis penelitian sebagai berikut:

Ha1 = Risiko klaim berpengaruh signifikan terhadap tingkat proporsi danatabarru'

\subsection{KONTRIBUSI RETAKAFUL}

Kontribusi retakaful atau yang dikenal dalam asuransi konvensional sebagai premi reasuransi merupakan dana kontribusi yang dibayarkan oleh perusahaan asuransi sebagai pengelola risiko ke perusahaan retakaful, dengan tujuan agar potensi risiko yang dimiliki disesikan atau dibagi dengan perusahaan retakaful (Bayinah et al., 2017, hlm. 104).. Kontribusi retakaful merupakan transaksi dana peserta, sehingga dana yang dibayarkan berasal dari bagian tertentu dana kontribusi peserta. Kontribusi retakaful ini secata otomatis nantinya akan mengurangi nilai dana tabarru'. 
Pengertian kegiatan retakaful pada dasarnya sama seperti reasuransi konvensional, hanya saja penekannya berbeda pada konsep dasarnya. Dimana bila melakukan kerjasama dengan retakaful menekankan adanya proses suka sama suka (saling menyepakati) risiko dan persyaratannya yang ditetapkan dalam akad. Dalam operasionalnya menggunakan prinsip-prinsip syariah, terbebas dari praktek gharar, maisir dan riba (Sula, 2004, hlm. 264). Yang sudah barang tentu menjadi suatu kewajiban bagi perusahaan asuransi dengan prinsip syariah melakukan kerjasama sesi risiko kepada reasuransi yang berprinsip syariah pula.Pembayaran kontribusi retakaful oleh perusahaan asuransi syariah pada umumnya mengharapkan timbal balik yang menguntungkan atau setidaknya menyelamatkan peusahaan.

Puspitasi (2011) menjelaskan bahwa kegiatan retakaful yang tinggi akan diikuti dengan peningkatan proporsi dana tabarru'. Oleh karena itu, berdasarkan teori dan penelitian sebelumnya yang telah diuraikan, dapat disusun hipotesis penelitian sebagai berikut:

Ha2 = Kontribusi Retakaful berpengaruh signifikan terhadap tingkat proporsi danatabarru'

\subsection{BEBAN OPERASIONAL}

Beban operasional ditanggung oleh pengelola merupakan seluruh pengeluaran yang menjadi beban perusahaan asuransi, diantaranya terdiri dari biaya komisi, beban pemasaran, beban umum dan administrasi, serta beban lainnya yang terkait (Bayinah et al., 2017, hlm. 124). Seluruh beban operasional tersebut dianggarkan dari pendapatan utama perusahaan yaitu feelujrah yang diterima dari peserta.

Kelompok akun ujrah/fee tersebut bersumber dari dana kontribusi bruto peserta sehingga menjadi beban ujrah bagi akun dana peserta dan akan mengurangi nilai kontribusi. Dalam fatwa DSN disebutkan kalau fee (ujrah) yang dibayarkan adalah "biaya yang dibebankan dari dana peserta sebagai fee pegelolaan yang digunakan untuk biaya operasional, komisi, dan lain sebagainya".

Berdasarkan Peraturan Ketua Bapepam-LK No : PER-06/BL/2011 tanggal 29 April 2011, bahwa beban operasional pengelola diakui sebagai biaya sebagaimana peruntukannya dan besarnya disesuaikan dengan jumlah yang diatribusikan pada transaksi yang terkait. Beban operasional disajikan secara terpisah sesuai peruntukannya dalam laporan laba rugi.

Puspitasi (2016) menyatakan bahwa semakin tinggi beban, maka akan diikuti oleh kebutuhan ujrah yang tinggi pula. Jika kebutuhan ujrah yang tinggi maka akan berakibat pada porsi dana tabarru' yang semakin rendah. Oleh karena itu, berdasarkan teori dan penelitian sebelumnya yang telah diuraikan, dapat disusun hipotesis penelitian sebagai berikut:

Ha3 = Beban Operasional berpengaruh signifikan terhadap tingkat proporsi danatabarru' 


\subsection{NILAI TUKAR RUPIAH}

Nilai tukar uang merepresentasikan tingkat harga pertukaran dari satu mata uang ke mata uang lainnya, dan digunakan dalam berbagai transaksi, antara lain perdagangan internasional ataupun aliran jangka pendek antar negara yang melewati batas-batas geografis atau batas-batas hukum (Sugiyono, 2008). Syarifuddin (2015) mengungkapkan bahwa kini transaksi yang melibatkan mata uang asing semakin berkembang melalui transaksi keuangan/investasi internasional.

Hal ini pun berakibat bagi sektor bisnis, yang tak sedikit mulai memperhatikan faktor pengaruh dari nilai tukar rupiah tersebut. Dimana nilai tukar rupiah adalah nilai yang menunjukkan jumlah mata uang dalam negeri yang diperlukan untuk mendapatkan satu unit mata uang asing. Nilai tukar rupiah yang digunakan dalam penelitian ini adalah nilai tukar rupiah terhadap USD. Rupiah bertindak sebagai mata uang domestik dan USD bertindak sebagai mata uang asing (Kuncoro, 2013).

Perubahan nilai tukar rupiah yang sangat cepat dan tidak stabil diyakini akan mengganggu kestabilan kegiatan perdagangan internasional dan berimbas pada pelarian modal internasional. Kondisi ini pada akhirnya dapat mengakibatkan depresiasi/melemahnya nilai rupiah terhadap USD, sehingga dapat menyebabkan capital outflow atau pelarian modal masyarakat keluar negeri karena jika dibandingkan dengan mata uang negara lain maka ekspektasi return investasi di Indonesia lebih rendah. Hal ini pun akan berakibat pada minat peserta asuransi jiwa syariah terlebih yang menggunakan produk saving untuk beralih ke investasi asing dan melepaskan dari kepesertaannya. Sehingga mengganggu iklim bisnis yang berpotensi membahayakan keberlangsungan hidup perusahaan.

Variabel nilai tukar rupiah ini dalam penelitian terdahulu oleh Affandi (2016) dan Arif (2011) membuktikan memiliki pengaruh yang signifikan terhadap proporsi nisbah bagi hasil pada bank syariah. Oleh karena itu, berdasarkan teori dan penelitian acuan sebelumnya yang telah diuraikan, dapat disusun hipotesis penelitian sebagai berikut:

Ha4 = Nilai tukar rupiah berpengaruh signifikan terhadap tingkat proporsi danatabarru'

\subsection{INFLASI}

Suseno \& Astiyah (2009) menjelaskan bahwa Inflasi diartikan sebagai kenaikan jumlah uang beredar atau kenaikan likuiditas dalam suatu perekonomian. Secara singkat, inflasi dapat diartikan sebagai suatu kecenderungan meningkatnya harga-harga barang dan jasa secara umum dan terus-menerus. Dengan inflasi, maka daya beli suatu mata uang menjadi lebih rendah atau menurun. Dengan menurunnya daya beli mata uang, maka kemampuan masyarakat berpendapatan tetap dalam membeli barang dan jasa kebutuhan sehari-hari akan menjadi semakin rendah.

Laju inflasi yang tidak stabil, merupakan gejala ekonomi yang menjadi perhatian berbagai pihak. Inflasi tidak hanya menjadi pehatian 
masyarakat umum, tetapi juga menjadi perhatian dunia usaha, bank sentral, dan pemerintah. Bagi masyarakat umum, inflasi dapat berpengaruh secara langsung terhadap kesejahteraan hidup. Sedang bagi dunia usaha, inflasi menjadi faktor yang sangat penting dalam membuat berbagai keputusan. Sebab dengan kecenderungan kenaikan inflasi diprediksi akan menurunkan minat masyarakat untuk berasuransi, begitupula sebaliknya jika penurunan inflasi akan mendorong masyarakat untuk mengikuti asuransi baik yang dengan prinsip syariah maupun tidak.

Variabel inflasi ini dalam penelitian terdahulu oleh Affandi(2016), Arfiani \& Mulazid(2017), dan Arif (2011) membuktikan memiliki pengaruh yang signifikan terhadap proporsi nisbah bagi hasil pada bank syariah. Oleh karena itu, berdasarkan teori dan penelitian acuan sebelumnya yang telah diuraikan, dapat disusun hipotesis penelitian sebagai berikut:

Ha5= Inflasi berpengaruh signifikan terhadap tingkat proporsi dana tabarru'

\subsection{SUKU BUNGA (BI-RATE)}

Bank Indonesia (2018) menjelaskan yang dimaksud tingkat suku bunga acuan atau yang disebut BI Rate adalah suku bunga kebijakan yang mencerminkan sikap atau stance kebijakan moneter yang ditetapkan oleh Bank Indonesia dan diumumkan kepada publik. BI Rate diumumkan oleh Dewan Gubernur Bank Indonesia setiap Rapat Dewan Gubernur bulanan dan diimplementasikan pada operasi moneter yang dilakukan Bank Indonesia melalui pengelolaan likuiditas (liquidity management) di pasar uang untuk mencapai sasaran operasional kebijakan moneter.

Sasaran operasional kebijakan moneter dicerminkan pada perkembangan suku bunga Pasar Uang Antar Bank Overnight (PUAB O/N). Pergerakan di suku bunga PUAB ini diharapkan akan diikuti oleh perkembangan suku bunga deposito, dan pada gilirannya suku bunga kredit perbankan, sehingga secara otomatis akan berefek pada industri keuangan lainnya, seperti asuransi jiwa syariah yang berpotensi besar mengikuti laju suku bunga acuan.

Dengan mempertimbangkan faktor lain dalam perekonomian, Bank Indonesia akan menaikkan BI Rate apabila inflasi ke depan diperkirakan melampaui sasaran yang telah ditetapkan, sebaliknya Bank Indonesia akan menurunkan BI Rate apabila inflasi ke depan diperkirakan berada dibawah sasaran yang telah ditetapkan.

Variabel suku bunga BI-Rate ini dalam penelitian terdahulu oleh Affandi (2016), Arif (2011), Kunti \& Sunaryo(2012), Romansyah (2009),dan Yuksel et al. (2017) membuktikan memiliki pengaruh yang signifikan terhadap proporsi nisbah bagi hasil pada bank syariah. Oleh karena itu, berdasarkan teori dan penelitian acuan sebelumnya yang telah diuraikan, dapat disusun hipotesis penelitian sebagai berikut:

Ha6 = Suku Bunga BI-Rate berpengaruh signifikan terhadap tingkat proporsi danatabarru' 
Adapun model penelitian digambarkan pada Gambar 1 yang didasarkan pada hipotesis penelitian sebagai berikut:

Gambar 1. Model Determinan Proporsi dana Tabarru'

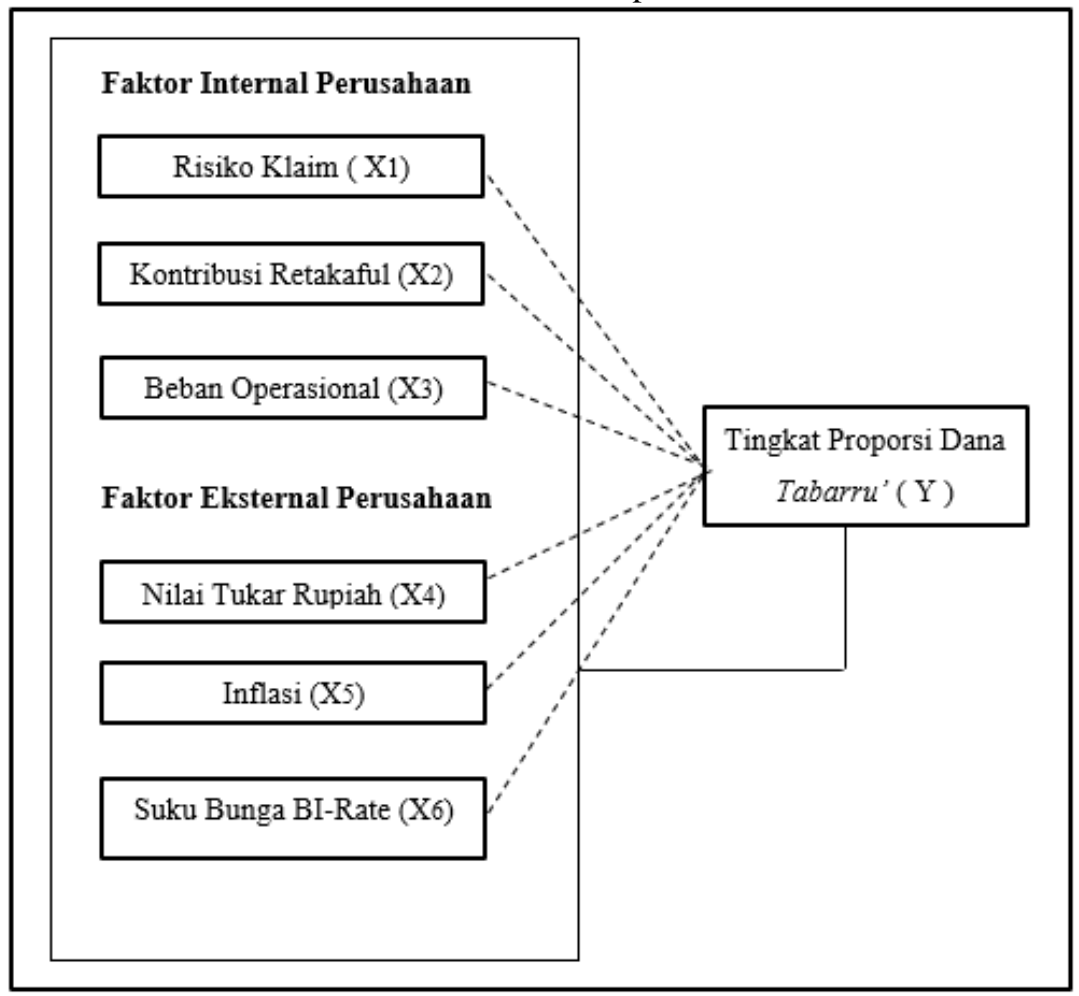

\section{METODE PENELITIAN}

Populasi dalam penelitian ini adalah seluruh laporan keuangan tahunan perusahaan asuransi jiwa syariah di Indonesia yang tercatat di Otoritas Jasa Keuangan per tahun 2017. Dimana terdapat 215 laporan keuangan dari 30 perusahaan asuransi jiwa syariah sejak awal berdirinya hingga tahun 2017. Serta seluruh data makroekonomi yang berkaitan dengan variable penelitian ini yang dipublikasikan oleh Bank Indonesia.

Setelah ditentukan populasi, selanjutnya adalah teknik pengambilan sampel dengan menggunakan teknik purposive sampling, dimana sampel diambil berdasarkan kesesuaian karakteristik dengan kriteria yang didasarkan atas kepentingan penelitian. Kriteria yang digunakan adalah sebagai berikut:

a. Laporan keuangan tahunan yang dipublikasikan oleh perusahaan asuransi jiwa syariah di Indonesia setelah memperoleh izin pendirian operasi hingga tahun 2017 
b. Publikasi laporan keuangan tahunan yang dapat diakses melalui website resmi masing-masing perusahaan dan sumber dari Otoritas Jasa Keuangan sejak tahun izin pendirian perusahaan asuransi jiwa syariah tersebut.

c. Mengungkapkan data-data yang berkaitan dengan variabel penelitian dan tersedia dengan lengkap dalam laporan keuangan tahunan sejak tahun izin pendirian perusahaan asuransi jiwa syariah tersebut.

d. Nilai angka makroekonomi yang dipublikasikan melalui website resmi Bank Indonesia, disesuaikan dengan perolehan data laporan keuangan tahunan perusahaan asuransi jiwa syariah hingga tahun 2017.

Setelah dilakukan pemilihan kriteria sampel, maka jumlah sampel dalam penelitian adalah sebagai berikut

Tabel 2. Objek dan Sampel Penelitian

\begin{tabular}{|c|c|}
\hline Kategori & Jumlah \\
\hline $\begin{array}{l}\text { Laporan keuangan tahunan yang dipublikasikan oleh } \\
\text { perusahaan asuransi jiwa syariah di Indonesia setelah } \\
\text { memperoleh izin pendirian operasi hingga tahun } 2017\end{array}$ & 215 \\
\hline $\begin{array}{l}\text { Laporan keuangan tahunan yang tidak dapat diakses melalui } \\
\text { website perusahaan maupun yang bersumber dari Otoritas Jasa } \\
\text { Keuangan sejak tahun izin pendirian hingga tahun } 2017\end{array}$ & $(63)$ \\
\hline $\begin{array}{l}\text { Tidak terungkapnya data-data yang berkaitan dengan variabel } \\
\text { penelitian dan tersedia dengan lengkap dalam laporan keuangan } \\
\text { tahunan hingga tahun } 2017\end{array}$ & (14) \\
\hline Jumlah Objek Penelitian yang dijadikan sampel & 138 \\
\hline Total Data sampel yang terpilih & 138 \\
\hline
\end{tabular}

Sumber : Data Diolah (2018)

Penelitian ini menggunakan 23 perusahaan asuransi jiwa syariah dengan rentang data dan periode yang berbeda sebagai sampel penelitian, serta 6 variabel independen (risiko klaim, kontribusi retakaful, beban operasional, nilai tukar rupiah, tingkat inflasi dan suku bunga BI-rate). Penggunaan data sampel ini disebut sebagai unbalance panel. Widarjono (2013, hlm. 354) menjelaskan jika setiap unit cross section mepunyai data time series yang sama maka modelnya disebut model regresi panel seimbang (balanced panel). Sedangkan jika jumlah observasi time series dari unit cross section tidak sama maka disebut regresi panel data tidak seimbang (unbalanced panel).

Tabel berikut adalah penjelasan terkait variabel independen dan tipe skala pengukurannya: 
Tabel 3. Variabel Penelitian dan Pengukuran

\begin{tabular}{|c|c|c|c|}
\hline $\mathrm{NO}$ & Variabel & Definisi dan Pengukuran & Skala \\
\hline 1 & $\begin{array}{l}\text { Proporsi } \\
\text { dana } \\
\text { Tabarru }\end{array}$ & $\begin{array}{l}\text { Dana tabarru' adalah komponen utama } \\
\text { kontribusi yang mencer-minkan } \\
\text { karakteristik transaksi asu-ransi } \\
\text { syariah.Kumpulan dana ta-barru' hanya } \\
\text { dapat dipergunakan untuk kepentingan } \\
\text { para peserta takaful (asuransi syariah) saja } \\
\text { yang mendapat musibah. Sekiranya dana } \\
\text { tabarru' tersebut digunakan untuk } \\
\text { kepentingan lain, ini berarti melanggar } \\
\text { syarat akad (Sula, 2004, hlm. 38). } \\
\quad \text { Proporsi dana tabarru' } \\
\quad=\frac{(K B-U P-K R-P K M B H)}{\text { K }} \% \\
\text { Ket : } \\
\text { KB }=\text { Kontribusi Bruto } \\
\text { UP = Ujroh Pengelola } \\
\text { KR = Kontribusi Retakaful } \\
\text { PKBMH = Perubahan Kontribusi yang } \\
\text { Belum Menjadi Hak }\end{array}$ & Rasio \\
\hline 1 & Risiko Klaim & $\begin{array}{l}\text { Merupakan nilai pertanggungan yang } \\
\text { diberikan ke peserta atas kerugian yang } \\
\text { dialaminya. Resi-ko klaim terdiri atas } \\
\text { pembayaran klaim ke peserta beserta } \\
\text { penyisi-han teknis lainnya. Semua risiko } \\
\text { klaim tersebut tertuang dalam beban } \\
\text { asuransi yang disajikan dalam Laporan } \\
\text { Surplus Defisit Underwriting. }\end{array}$ & Rasio \\
\hline 2 & $\begin{array}{l}\text { Kontribusi } \\
\text { Retakaful }\end{array}$ & $\begin{array}{l}\text { Merupakan transaksi dana peser-ta, } \\
\text { sehingga dana yang dibayar-kan berasal } \\
\text { dari bagian tertentu dana kontribusi brotu } \\
\text { peserta. Sehingga kontribusi retakaful ini } \\
\text { akan mengurangi dana tabarru'. Angka } \\
\text { kontribusi retakaful yang digunakan } \\
\text { dalam penelitian ini adalah angka bagian } \\
\text { kontribusi retakaful yang disajikan dalam } \\
\text { Laporan Surplus Defisit Under-writing. }\end{array}$ & Rasio \\
\hline 3 & $\begin{array}{l}\text { Beban } \\
\text { Operasional }\end{array}$ & $\begin{array}{l}\text { Meliputi seluruh pengeluaran yang } \\
\text { menjadi beban perusahaan asuransi, } \\
\text { diantaranya terdiri dari biaya komisi, } \\
\text { beban pemasaran, beban umum dan } \\
\text { administrasi, serta beban-beban lainnya } \\
\text { yang terkait. Angka beban operasional } \\
\text { yang digunakan dalam penelitian ini }\end{array}$ & Rasio \\
\hline
\end{tabular}




\begin{tabular}{|c|c|c|c|}
\hline & & $\begin{array}{l}\text { adalah angka beban opera-sional yang } \\
\text { disajikan dalam laporan laba rugi } \\
\text { perusahaan. }\end{array}$ & \\
\hline 4 & $\begin{array}{l}\text { Nilai Tukar } \\
\text { Rupiah }\end{array}$ & $\begin{array}{l}\text { Nilai tukar rupiah yang di-gunakan dalam } \\
\text { penelitian ini adalah perubahan nilai tukar } \\
\text { rupiah terhadap USD. Rupiah bertindak } \\
\text { sebagai mata uang domestik dan USD } \\
\text { bertindak sebagai mata uang asing. Data } \\
\text { kurs nilai tukar Rupiah terhadap USD } \\
\text { yang digunakan dalam penelitian ini } \\
\text { merupakan nilai kurs tengah yang dasar } \\
\text { perhitungannya diambil dari website } \\
\text { resmi Bank Indonesia: } \\
\text { http://www.bi.go.id. }\end{array}$ & Rasio \\
\hline 5 & Inflasi & $\begin{array}{l}\text { Biasanya disajikan dalam per-sentase } \\
\text { perubahan angka indeks. Indikator yang } \\
\text { sering digunakan untuk mengukur tingkat } \\
\text { inflasi adalah indeks harga konsumen } \\
\text { (IHK). Data inflasi yang digunakan dalam } \\
\text { penelitian ini diambil dari website resmi } \\
\text { Bank Indonesia : http://www.bi.go.id }\end{array}$ & Rasio \\
\hline 6 & $\begin{array}{l}\text { Tingkat Suku } \\
\text { Bunga ( BI- } \\
\text { Rate) }\end{array}$ & $\begin{array}{l}\text { BI-Rate adalah nilai suku bunga kebijakan } \\
\text { yang mencerminkan sikap atau stance } \\
\text { kebijakan moneter yang ditetapkan oleh } \\
\text { Bank Indonesia dan diumumkan kepada } \\
\text { publik. Data tingkat suku bunga acuan } \\
\text { dalam penelitian ini diambil dari website } \\
\text { resmi Bank Indonesia : } \\
\text { http://www.bi.go.id }\end{array}$ & Rasio \\
\hline
\end{tabular}

\section{ANALISIS DATA DAN PEMBAHASAN}

\subsection{STATISTIK DESKRIPTIF}

Analisis statistik deskriptif data penelitian terangkum pada Tabel 2. Untuk variabel R_KLM, K_Reta, dan B_Opr adalah menggunakan data nilai angka yang diperoleh dalam laporan keuangan perusahaan asuransi jiwa syariah yang disajikan dalam satuan jutaan rupiah. Sedangkan untuk NTR adalah mengunakan data nilai angka berupa satuan ribuan yang diperoleh dari situs resmi website Bank Indonesia yaitu 1 dollar USD terhadap rupiah. Sementara untuk variabel IFL dan SB_BI adalah menggunakan angka persentase yang didesimalkan yang diperoleh dari website resmi Bank Indonesia. Sehingga, untuk keseimbangan data keempat variabel independen yaitu R_KLM, 
K_Reta, B_Opr, dan NTR menggunakan data yang diinterprestasikan dengan data log saat tabulasi awal.

Tabel 4. Hasil Analisis Statistik Deskriptif

\begin{tabular}{lccccrrr}
\hline & PDT & $\begin{array}{c}\text { R_KL } \\
\text { M }\end{array}$ & $\begin{array}{c}\text { K_RE } \\
\text { TA }\end{array}$ & B_OPR & NTR & IFLS & $\begin{array}{c}\text { SK_B } \\
\text { I }\end{array}$ \\
\hline Mean & 0.38 & 23.00 & 22.03 & 24.08 & 9.37 & 0.05 & 0.07 \\
\hline Median & 0.38 & 23.20 & 22.03 & 23.77 & 9.43 & 0.038 & 0.07 \\
\hline Max. & 0.96 & 26.55 & 25.82 & 27.58 & 9.53 & 0.084 & 0.08 \\
\hline Min. & 0.03 & 17.99 & 16.12 & 19.18 & 9.10 & 0.032 & 0.06 \\
\hline Std. & 0.20 & 1.806 & 1.991 & 1.559 & 0.16 & 0.022 & 0.01 \\
Dev & 0.07 & 0.113 & 0.114 & 0.784 & 0.00 & 0.00 & 0.00 \\
\hline Prob. & 138 & 138 & 138 & 138 & 138 & 138 & 138 \\
\hline Obs & \multicolumn{7}{c}{ Sumber: Hasil Output Eviews 9 (2018) } \\
\hline \multicolumn{7}{c}{} \\
\end{tabular}

Keterangan:

$\begin{array}{ll}\text { PDT } & =\text { Proporsi Dana Tabarru' } \\ \text { R_KLM } & =\text { Risiko Klaim } \\ \text { K_RETA } & =\text { Kontribusi Retakaful } \\ \text { B_OPR } & =\text { Beban Operasional } \\ \text { NTR } & =\text { Nilai Tukar Rupiah } \\ \text { IFLS } & =\text { Inflasi } \\ \text { SK_BI } & =\text { Suku Bunga BI Rate }\end{array}$

Berdasarkan pada Tabel 4 dapat diketahui bahwa nilai rata-rata tingkat Proporsi Dana Tabarru' (PDT) adalah 38,5\%, dengan nilai tengah yaitu sebesar $37,6 \%$. Nilai maksimum sebesar $95,7 \%$ merupakan proporsi dana tabarru' paling tinggi dari total data yang diteliti, yaitu PDT PT Panin Dai-ichi Life pada tahun 2010. Sedangkan nilai minimum sebesar 3,4\% merupakan proporsi dana tabarru' paling rendah dari total data yang diteliti yaitu PDT PT Asuransi Allianz Life Indonesia pada tahun 2012. Sementara standar deviasi dengan nilai 0.20348 menunjukkan simpangan baku yang relatif kecil karena nilainya lebih kecil daripada nilai rata-rata.

Risiko Klaim (R_KLM) memiliki nilai rata-rata sebesar 23.0044, dengan nilai tengah sebesar 23.2025. Menunjukkan nilai maksimum dari data penelitian sebesar 26.5540 dan nilai minimum sebesar 17.9900. Sementara standar deviasi dengan nilai 1.80687, menunjukan bahwa simpangan baku yang semakin kecil semakin akurat, yang berarti distribusi data yang semakin mendekati normalitas (Sarwono, 2016, hlm. 56-57).

Kontribusi Retakaful (K_RETA) memiliki nilai rata-rata sebesar 22.0319, dengan nilai tengah sebesar 22.0295. Menunjukkan nilai masimum dalam penelitian sebesar 25.8200 dan nilai minimum sebesar 16.1180. Sementara standar deviasi menunjukkan nilai 1.99110 yang berarti 
menunjukkan nilai simpangan baku yang semakin kecil dan semakin mendekati distribusi data normal.

Beban Operasional (B_OPR) memiliki nilai rata-rata sebesar 24.0843 dan nilai tengah sebesar 23.7260. Dalam penelitian ini menunjukkan nilai maksimum sebesar 27.5830 dan nilai minimum sebesar 19.1810. Sementara standar deviasi sebesar 1.55988 yang menunjukkan nilai simpangan baku yang semakin kecil dan semakin mendekati distribusi data normal.

Nilai Tukar Rupiah (NTR) memiliki nilai rata-rata sebesar 9.37497, dengan nilai tengah sebesar 9.42900. Menunjukkan nilai maksimum sebesar 9.53200 dan nilai minimum sebesar 9.10400. Sementara nilai standar deviasi sebesar 0.16441. Dari data tersebut kita bisa melihat nilai mean, median, dan minimum memiliki nilai yang saling berdekatan atau tidak berbeda jauh dengan nilai data maksimum. Artinya data yang bersifat homogen dan mendekati normalitas.

Inflasi (IFLS) dalam penelitian ini memiliki nilai rata-rata sebesar 0.05155 atau senilai $5 \%$, dengan nilai tengah sebesar 0,0380 atau senilai $3,8 \%$. Menunjukkan nilai maksimum sebesar 0,084 atau senilai $8,4 \%$ dan nilai minimum sebesar 0,032 sebesar 3,2\%. Sementara standar deviasi sebesar 0.02173 menunjukkan simpangan baku yang relatif kecil karena nilainya lebih kecil daripada nilai rata-rata.

Suku Bunga BI-Rate (SK_BI) dalam penelitian ini memiliki nilai ratarata sebesar 0.06806 atau senilai $6,8 \%$, dengan nilai tengah sebesar 0,065 atau senilai $6,5 \%$. Menunjukkan nilai maksimum sebesar 0,078 atau senilai $7,8 \%$ dan nilai minimum sebesar 0,058 atau senilai $5,8 \%$. Sementara standar deviasi sebesar 0.00705 menunjukkan data tersebut memiliki nilai yang saling berdekatan dan bersifat homogen, dimana nilai simpangan baku yang semakin kecil semakin akurat.

\subsection{HASIL UJI REGRESI PANEL}

Selanjutnya, untuk menjawab tujuan penelitian, penelitian ini menggunkan alat analisis regresi panel. Namun, sebelum melakukan analisis regresi panel, penelitian ini diawali dengan pemilihan estimasi pendekatan parameter model yang tepat. Berdasarkan hasil Uji statistik F (Uji Chow) disimpulkan bahwa Fixed Effect Model (FEM) lebih tepat dibandingkan dengan Common Effect Model (CEM). Dibuktikan dengan nilai probabilitas Cross-section F adalah 0,0000< 0,05. Namun demikian, berdasarkan pengujian Hausman Testdisimpulkan bahwa Random Effect Model (REM)lebih tepat dibandingkan Fixed Effect Model(FEM). Dibuktikan dengan dilihat nilai probabilitas Cross-section random adalah 0,3624>0,05. Maka dilakukan Uji Lagrangge Mutlipier Testyangmerupakan pengujian untuk mengetahui apakah Random Effect Model (REM) atau Common Effect Model (CEM) yang paling tepat digunakan. Dari uji LM dapat disimpulkan bahwa Random Effect Model (REM) lebih tepat digunakan dibandingkanCommon Effect Model (CEM), dibuktikan dengan nilai P-value adalah 0,0000<0,05.

Setelah dilakukan serangkaian pengujian untuk mengetahui model mana yang terbaik digunakan antara CEM, FEM, dam REM, maka diketahui 
bahwa model REM lebih cocok digunakan dalam penelitian ini. Maka tidak perlu dilakukan uji asumsi klasik agar memenuhi BLUE (Best Linier Unbiased Estimator) untuk masuk ke pengujian hipotesis, karena hal tersebut telah terpenuhi. Dimana hasil model Random Effect (RE) pada Eviews menggunakan metode Generalized Least Square (GLS) (Gujarati \& Porter, 2012).

Tabel 5. Hasil Random Effect Model (REM)

\begin{tabular}{crrrr}
\hline Variable & Coefficient & Std. Error & t-Statistic & Prob. \\
\hline R_KLM & 0.105746 & 0.015951 & 6.629618 & 0.0000 \\
\hline K_RETA & -0.086537 & 0.013649 & -6.340286 & 0.0000 \\
\hline B_OPR & -0.054128 & 0.017229 & -3.141708 & 0.0021 \\
\hline NTR & -0.041679 & 0.107024 & -0.389440 & 0.6976 \\
\hline IFLS & 0.271572 & 0.748215 & 0.362959 & 0.7172 \\
\hline SK_BI & 0.629170 & 2.891646 & 0.217582 & 0.8281 \\
\hline C & 1.489716 & 0.851114 & 1.750312 & 0.0824 \\
\hline R-squared & 0.345972 & Mean dependent var & 0.122118 \\
\hline $\begin{array}{l}\text { Adjusted R- } \\
\text { squared }\end{array}$ & 0.316017 & S.D. dependent var & 0.127189 \\
\hline S.E. of regression & 0.103793 & Sum squared resid & 1.411251 \\
\hline F-statistic & 11.54956 & Durbin-Watson stat & 1.379335 \\
\hline Prob(F-statistic) & 0.000000 & & \\
\hline
\end{tabular}

Sumber: Output uji Random Effect Model dengan Eviews 9(2018)

Dari hasil pengujian regresi menggunakan Random Effect Model (REM) diatas, maka didapat persamaan regesinya sebagai berikut:

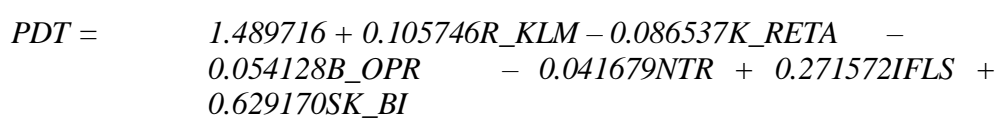

Persamaan tersebut dapat diinterprestasikan bahwa jika Risiko Klaim (R_KLM) mengalami peningkatan sebesar 1\%, maka Proporsi Dana Tabarru' (PDT) akan terjadi peningkatan sebesar 10\% (0.105746). Jika Kontribusi Retakaful (K_RETA) mengalami peningkatan sebesar 1\%, maka PDT akan menurun sebesar 8,6\% (0,086537). Jika Beban Operasional (B_OPR) mengalami peningkatan sebesar 1\%, maka PDT akan menurun sebesar 5,4\% (0,054128). Jika Nilai Tukar Rupiah (NTR) mengalami peningkatan sebesar $1 \%$, maka PDT akan menurun sebesar 4\% $(0,041679)$. Jika Inflasi (IFLS) mengalami peningkatan sebesar 1\%, maka akan terjadi kenaikan PDT sebesar 27\% (0,27152). Dan jika Suku Bunga BI-Rate (SK_BI) mengalami peningkatan sebesar 1\%, maka akan terjadi kenaikan PDT sebesar 62\% (0.629170).

Nilai konstanta (intercept) sebesar 1.489716 bermakna bahwa jika variabel R_KLM, K_RETA, B_OPR, NTR, IFLS, dan SK_BI tetap atau 
tidak berubah, maka Tingkat PDT akan mengalami peningkatan sebesar $148 \%$.

Berdasarkan tabel diatas diketahui nilai $R$-squared sebesar 0.345972 . Nilai tersebut menunjukkan bahwa variabel dependen (PDT) dapat dijelaskan oleh variabel independennya sebesar 34,5\%. Atau dengan kata lain, Risiko Klaim, Kontribusi Retakaful, Beban Operasional, Nilai Tukar Rupiah, Inflasi, dan Suku Bunga BI-Rate bepengaruh sebesar 34,5\% terhadap tingkat Proporsi Dana Tabarru'. Sedangkan sisanya sebesar 65,5\% (100\%-34,5\%) dijelaskan oleh variabel lain.

\subsection{PEMBAHASAN}

Penelitian ini membuktikan bahwa Risiko Klaim, Kontribusi Retakaful, Beban Operasional, Nilai Tukar Rupiah, Inflasi, dan Suku Bunga BI-Rate bepengaruh signifikan terhadap tingkat proporsi dana tabarru' pada asuransi jiwa Syariah. Dimana, penelitian ini sejalan dengan Purwocaroko \& Suprayogi (2016) dan Puspitasari (2011, 2012, 2016) yang menyatakan bahwa risiko klaim, kontribusi retakaful dan beban operasional perusahaan berpengaruh secara simultan terhadap proporsi dana tabarru'. Adapun untuk variabel makroekonomi dalam penelitian ini merupakan pengembangan penelitian pertama kali untuk menguji pengaruhnya terhadap proporsi danatabarru' pada perusahaan asuransi jiwa syariah. Dengan mengacu pada konsep proporsi bagi hasil di bank syariah yang penelitiannya telah dilakukan oleh Arif (2011), Kunti \& Sunaryo (2012), Romansyah (2009), Yuksel et al.,(2017), Affandi (2016) dan Arfiani \& Mulazid (2017), pengambilan variabel nilai tukar rupiah, tinkat inflasi, dan suku bunga BI-Rate menunjukkan hasil yang berpengaruh secara simultan terhadap proporsi dana tabarru'.

Hal ini menunjukkan tidak hanya faktor internal perusahaan saja yang perlu diperhatikan oleh manajemen, melainkan faktor ekternal perusahaan pun perlu dipertimbangkan dalam memutuskan kebijakan terhadap tingkat proporsi danatabarru', dimana perusahaan dapat lebih berhati-hati demi keberlangsungan usahanya agar tidak menanggung beban risiko yang lebih tinggi.

Berikut ini adalah bahasan tentang variable yang terbukti berpengaruh secara parsial terhadap tingkat proporsi danatabarru':

1. Risiko Klaim Berpengaruh Secara Parsial Terhadap Tingkat Proporsi Dana Tabarru'

Pada penelitian ini, analisis regresi menunjukkan hasil bahwa variabel risiko klaim (R_KLM) memiliki nilai koefisien sebesar 0.105746 dengan nilai signifikansi sebesar 0.0000. Berdasarkan hasil tersebut dapat disimpulkan bahwa variabel risiko klaim berpengaruh positif signifikan terhadap tingkat proporsi danatabarru'.Artinya, ketika risiko klaim mengalami peningkatan maka proporsi danatabarru' akan secara beriringan meningkat juga. Dan sebaliknya, ketika risiko klaim menurun maka proporsi danatabarru' akan ikut menurun. 
Hasil penelitian ini sejalan dengan penelitian yang dilakukan oleh Puspitasari (2016) dan Purwocaroko \& Suprayogi (2016) yang menyatakan bahwa faktor risiko klaim berpengaruh positif terhadap proporsi dana tabarru'. Artinya semakin besar potensi risiko klaim maka semakin besar pula proporsi danatabarru' yang harus disediakan.

Puspitasari (2011) menjelaskan bahwa peningkatan risiko klaim bisa disebabkan oleh 2 hal, pertama pada kondisi alam dan lingkungan yang tidak bisa diprediksi. Pada saat terjadi bencana alam seperti gempa, banjir, kebakaran, dan kecelakaan, maka dipastikan nilai klaim akan meningkat. Kedua bergantung pada analisis dalam akseptasi objek (peserta) yang kurang valid. Proses akseptasi harus dilakukan dengan analisa risiko yang tepat.

Apabila hal-hal yang bisa menyebabkan terjadinya risiko klaim tersebut bisa diminimalkan atau paling tidak sesuai dengan prediksi klaim di awal periode, maka terdapat harapan danatabarru' mampu mengimbangi risiko yang terjadi. Sehingga apabila terjadi risiko klaim yang meningkat, maka untuk periode selanjutnya perusahaan sudah harus mengestimasi proporsi danatabarru' yang lebih tinggi. Dimana dalam perusahaan asuransi syariah faktor kedinamisan lingkungan sekitar, terlebih pada musibah yang terjadi tidak dapat diprediksi kapan datangnya sehingga berakibat pada kedinamisan variabel risiko klaim.

2. Kontribusi Retakaful Berpengaruh Secara Parsial Terhadap Tingkat Proporsi Dana Tabarru'

Hasil analisis regresi menunjukkan bahwa variabel kontribusi retakaful dalam penelitian ini memiliki nilai koefisien sebesar -0.088501 dengan nilai signifikansi sebesar 0.0000 . Berdasarkan hasil tersebut dapat disimpulkan bahwa kontribusi retakaful berpengaruh negatif signifikan terhadap tingkat proporsi danatabarru'.Artinya, ketika kontribusi retakaful mengalami peningkatan maka proporsi danatabarru' akan menurun. Dan sebaliknya, ketika kontribusi retakaful menurun maka proporsi danatabarru' akan meningkat.

Pada hasil penelitian ini juga dapat disimpulkan bahwa proporsi danatabarru' dan kontribusi retakaful menunjukkan hubungan yang negatif diantara keduanya, dengan pola linier yang saling bertolak belakang. Meskipun pada beberapa perusahaan ada data nilai kontribusi retakaful dan proporsi danatabarru' yang cenderung positif mengikuti. Pengaruh positif tersebut bisa kita asumsikan dipengaruhi oleh permintaan manajemen dalam menetapkan nilai kontribusi bruto yang harus dibayarkan peserta lebih tinggi (Puspitasari, 2016), serta faktor-faktor lainnya diluar dari nilai kontribusi retakaful.

Hasil penelitian ini sejalan dengan penelitian yang telah dilakukan oleh Puspitasari (2011) yang menyatakan bahwa pembayaran kontribusi retakaful berpengaruh terhadap proporsi dana tabarru'. Kegiatan retakaful harus benar-benar diperhitungkan karena tingginya frekuensi pembayaran kontribusi retakaful akan mengurangi proporsi cadangan klaim bagi peserta serta berkurangnya porsi untuk investasi. 
Padahal pembayaran kontribusi retakaful tersebut pada umumnya diharapkan memberikan timbal balik yang menguntungkan atau setidaknya menyelamatkan perusahaan. Menyikapi hal tersebut, Otoritas Jasa Keuangan telah mengeluarkan POJK.05 Nomor 10 tahun 2015 tentang Retensi Sendiri dan Dukungan Reasuransi dalam Negeri serta PER-11/BL/2012 tentang Dukungan Reasuransi, Batas Retensi Sendiri, serta Bentuk dan Susunan Laporan Program Reasuransi. Dengan adanya peraturan ini perusahaan asuransi jiwa syariah dapat mengendalikan risikonya dengan retensi sendiri yang bertujuan, agar perusahaan mampu memperkecil bahaya yang dihadapi hingga tingkat yang dapat diterima dalam batas kesanggupan.

Dalam peraturan tersebut tidak disebutkan secara pasti batas retensi yang harus ditetapkan perusahaan, namun terdapat rentang retensi. Penentuan batas maksimum rentensi sendiri asuransi jiwa adalah $10 \%$ dari modal sendiri untuk setiap risiko, sedangkan batas minimumnya wajib mempertimbangkan persentase tertentu dari modal sendiri untuk setiap risiko dan besaran premi bruto yang harus ditahan untuk setiap lini usaha. Sehingga pembayaran kontribusi retakaful oleh perusahaan asuransi jiwa syariah dapat lebih diperhitungkan guna meng-efesiensikan penggunaan dana.

\section{Beban Operasional Berpengaruh Secara Parsial Terhadap Tingkat Proporsi Dana Tabarru'}

Pada penelitian ini, hipotesis pertama yang diajukan yaitu beban operasional berpengaruh signifikan terhadap tingkat proporsi danatabarru'. Hasil analisis regresi menunjukkan bahwa variabel beban operasional dalam penelitian ini memiliki nilai koefisien sebesar -0.054128 dengan nilai signifikansi sebesar 0.0021. Berdasarkan hasil tersebut dapat disimpulkan bahwa beban operasional berpengaruh negatif signifikan terhadap tingkat proporsi danatabarru'. Artinya, ketika beban operasional mengalami peningkatan maka proporsi danatabarru' akan menurun. Dan sebaliknya, ketika beban operasional menurun maka proporsi danatabarru' akan meningkat.

Hasil penelitian ini sejalan dengan penelitian yang telah dilakukan oleh Puspitasari (2016), yang menyatakan bahwa beban operasional berpengaruh negatif terhadap proporsi dana tabarru'. Dimana beban operasional ini merupakan komponen biaya yang dibayarkan dari kumpulan dana perusahaan. Yang sumber utama dana perusahaan adalah dari kontribusi bruto, sehingga berpotensi mengurangi nilai proporsi dana tabarru'.

Puspitasari (2012) dalam penelitian sebelumnya mengungkapkan, bahwa perusahaan asuransi syariah memiliki pertimbangan-pertimbangan dalam menentukan besaran proporsi tabarru' dan ujrah antara lain: (1) adanya etika bahwa tabarru' tidak boleh lebih kecil dari ujrah karena yang harus diutamakan adalah usaha tolong menolongnya, (2) kesepakatan dengan pihak retakaful yang berhubungan dengan claim records dari tahun sebelumnya, (3) operational expenses.

Semakin besar beban operasional perusahaan yang dibutuhkan maka semakin besar pula ujrah yang diharapkan perusahaan, yang pada akhirnya berpotensi pada proporsi ujrah yang meningkat dan menyebabkan proporsi 
danatabarru' menjadi lebih rendah. Biaya operasional tersebut selain dari ujrah yang diterima perusahaan, juga dapat dicover dari bagian surplus pengelolaan danatabarru' yang dibagikan. Namun demikian, jika perusahaan dapat melakukan pengelolaan dana dengan efesien, maka bisa diprediksi perusahaan akan mendapatkan keuntungan walaupun hanya dari ujrah saja. Sehingga, semakin efesien perusahaan maka expected return dari ujrah yang akan diterima tetap besar tanpa harus memperkecil proporsi dana tabarru'.

4. Nilai Tukar Rupiah Tidak Berpengaruh Secara Parsial Terhadap Tingkat Proporsi Dana Tabarru'

Perubahan nilai tukar rupiah yang sangat cepat dan tidak stabil diyakini akan mengganggu kestabilan bisnis asuransi jiwa syariah, akan tetapi dalam penelitian ini, hipotesis pertama yang diajukan yaitu nilai tukar rupiah berpengaruh signifikan terhadap tingkat proporsi dana tabarru'. Hasil analisis regresi menunjukkan bahwa variabel nilai tukar rupiah dalam penelitian ini memiliki nilai koefisien sebesar -0.041679 dengan nilai signifikansi sebesar 0.6976. Berdasarkan hasil tersebut dapat disimpulkan bahwa nilai tukar rupiah tidak berpengaruh signifikan terhadap tingkat proporsi danatabarru'.

Tidak adanya linearitas pada penelitian ini karena ketika proporsi danatabarru' mengalami naik atau turun secara fluktuatif, nilai tukar rupiah pada penelitian ini tetap dalam keadaan stabil, sekalipun mengalami perubahan naik- turunnya tidaklah mencerminkan keadaan yang fluktuatif jauh. Hal ini disebabkan jika terjadi perubahan pada nilai tukar rupiah, besaran nilainya berlaku untuk semua perusahaan asuransi jiwa syariah, tidak memandang ukuran besar kecil perusahaan tersebut, sehingga perusahaan dalam ukuran apapun akan tetap memperhatikan kebijakan pemerintah tersebut.

Perbedaan hasil yang didapatkan penelitian ini dengan acuan penelitian sebelumnya juga dipengaruhi oleh faktor lain. Yaitupenetapan objek penelitian dan variabel dependen yang berbeda dengan penelitian sebelumnya, dimana Affandi (2016) dan Arif (2011) keduanya menggunakan objek bank syariah untuk meneliti pengaruh tingkat nisbah bagi hasil. Meskipun berbeda, perlu ditekankan bahwa penelitian ini dengan penelitian sebelumnya memiliki kesamaan konsep dasar guna mencari pengaruh proporsi danatabarru' dengan proporsi nisbah bagi hasil.

Namun demikian, hasil penelitian ini mendukung pernyataan yang dilakukan oleh Puspitasari, (2012) yang menyebutkan bahwa nilai tukar rupiah terhadap dolar Amerika tidak berpengaruh secara langsung terhadap aspek penentuan proporsi dana tabarru' namun berpengaruh secara langsung terhadap aspek keuangan internal perusahaan misalnya berpengaruh terhadap tinggi rendahnya management expenses dan nilai tingkat pengembalian investasi (return on investment) dan berpengaruh pada tinggi rendahnya pembayaran klaim. 
5. Inflasi Tidak Berpengaruh Secara Parsial Terhadap Tingkat Proporsi Dana Tabarru'

Bagi dunia usaha, inflasi menjadi faktor yang sangat penting dalam membuat berbagai keputusan. Sebab dengan kecenderungan kenaikan inflasi dapat diprediksi akan menurunkan minat masyarakat untuk berasuransi, begitupula sebaliknya jika penurunan inflasi akan mendorong masyarakat untuk mengikuti asuransi baik yang dengan prinsip syariah maupun tidak.

Pada penelitian ini, hipotesis pertama yang diajukan yaitu tingkat inflasi berpengaruh signifikan terhadap tingkat proporsi danatabarru'. Hasil analisis regresi menunjukkan bahwa variabel tingkat inflasi dalam penelitian ini memiliki nilai koefisien sebesar 0.271572 dengan nilai signifikansi sebesar 0.71712. Berdasarkan hasil tersebut dapat disimpulkan bahwa inflasi tidak berpengaruh signifikan terhadap tingkat proporsi danatabarru'.

Dalam penelitian ini sebagai contoh, unit usaha syariah PT AIA Financial pada tahun 2013 proporsi dana tabarru' ditetapkan sebesar 5\% dan 2014 sebesar 7\% kondisi itu terjadi ketika inflasi yang ditetapkan dalam kondisi yang sama sebesar $8 \%$, kemudian terjadi peningkatan proporsi dana tabarru' pada tahun berikutnya ditahun 2015 dan 2016 menjadi 8\% ketika inflasi mengalami penurunan menjadi 3\%. Artinya jika inflasi meningkat maka proporsi danatabarru' menurun. Begitu sebaliknya, hal ini mencerminkan terjadinya pengaruh negatif, kondisi tersebut dalam penelitian ini hanya terjadi pada beberapa perusahaan dengan ukuran yang kecil.

Sebagaimana penjelasan hasil nilai tukar rupiah, kondisi variabel inflasi juga merupakan kebijakan pemerintah yang berlaku untuk semua perusahaan asuransi jiwa syariah, tidak memandang ukuran perusahaan karena merupakan variabel yang bersifat makro. Sehingga, ketika proporsi danatabarru' mengalami naik atau turun secara fluktuatif, inflasi pada penelitian ini tetap dalam keadaan stabil, sekalipun mengalami perubahan naik-turunnya tidaklah mencerminkan keadaan yang fluktuatif jauh.

Penelitian ini mendukung penelitian sebelumnya oleh Arfiani \& Mulazid (2017), Affandi (2016) dan Puspitasari (2012), dimana Puspitasari (2012) menyebutkan bahwa inflasi tidak berpengaruh secara langsung terhadap aspek penentuan proporsi dana tabarru' namun berpengaruh secara langsung terhadap aspek keuangan internal perusahaan bukan pada penetapan proporsi dana tabarru'.

\section{BI-Rate Tidak Berpengaruh Secara Parsial Terhadap Tingkat Proporsi Dana Tabarru'}

Asuransi jiwa syariah yang berpotensi besar mengikuti laju suku bunga acuan. Akan tetapi pada penelitian ini, hipotesis pertama yang diajukan yaitu tingkat suku bunga BI-Rate berpengaruh signifikan terhadap tingkat proporsi danatabarru'. Hasil analisis regresi menunjukkan bahwa variabel tingkat suku bunga BI-Rate dalam penelitian ini memiliki nilai koefisien sebesar 0.629170 dengan nilai signifikansi sebesar 0.8281. Berdasarkan hasil tersebut dapat disimpulkan bahwa suku bunga BI-Rate tidak berpengaruh signifikan terhadap tingkat proporsi danatabarru'. 
Penelitian ini bertentangan dengan penelitian acuan sebelumnya yang telah dilakukan oleh Kunti \& Sunaryo (2012); Romansyah (2009); dan Yuksel et al., (2017) yang menyatakan bahwa variabel suku bunga menjadi faktor yang mempengaruhi tingkat bagi hasil di bank syariah. Bahkan Yuksel et al., (2017) menyebutkan itu sebagai faktor utama. Perbedaan hasil penelitian ini selain dipengaruhi oleh perbedaan penetapan objek dan variabel dependennya sebagaimana telah dijelaskan pada bagian analisis hasil pengaruh nilai tukar rupiah, juga dipengaruhi oleh faktor lainnya.

Diantara inflasi dan suku bunga memiliki keterkaitan satu sama lain, dimana jika semakin tinggi suku bunga, maka akan semakin tinggi pula tingkat inflasinya. Sehingga dapat diasumsikan faktor ini pula yang mempengaruhi perbedaan hasil penelitian dengan yang sebelumnya.Misalnya jika dilihat dari kebijakan uang ketat dengan menaikkan suku bunga melalui operasi pasar terbuka, memang akan berdampak positif bila dilihat dari sisi penekanan jumlah uang yang beredar. Akan tetapi dilain sisi, hal ini akan menimbulkan masalah dalam sektor riil akibat dana masyarakat terserap semuanya ke perbankan. Sehingga produksi nasional melambat, harga-harga meningkat, daya beli masyarakat menurun dan diikuti pula dengan menurunnya minat masyarakat untuk berasuransi, efeknya bagi perusahaan asuransi jiwa syariah akan menurunnya nilai pendapatan kontribusi bruto pada tahun berjalan. Namun tidak secara langsung berpengaruh kepada penetapan proporsi danatabarru'.

\section{SIMPULAN}

Penelitian ini bertujuan untuk menguji pengaruh risiko klaim, kontribusi retakaful, beban operasional, nilai tukar rupiah, tingkat inflasi dan suku bunga BI-Rate terhadap tingkat proporsi danatabarru'. Metode analisis dalam penelitian adalah regresi berganda dengan jenis data unbalanced panel. Dimana penelitian ini menggunakan jumlah data sebanyak 138 dari rentang data dan periode yang berbeda, dengan sampel yang digunakan adalah 23 perusahaan asuransi jiwa syariah yang dipilih berdasarkan teknik purposive sampling dengan periode penelitian dari tahun 2010-2017.

Berdasarkan pengujian, analisis dan pembahasan, secara ringkas hasil penelitian ini menunjukkan bahwa variabel risiko klaim (R_KLM) secara parsial mempunyai pengaruh positif signifikan terhadap tingkat proporsi danatabarru', variabel kontribusi retakaful (K_RETA) dan beban operasional (B_OPR) secara parsial mempunyai pengaruh negatif signifikan terhadap tingkat proporsi dana tabarru'. Adapun variabel makroekonomi yaitu nilai tukar rupiah (NTR),tingkat Inflasi (IFLS), dan suku bunga BI-Rate (SK_BI) secara parsial tidak mempunyai pengaruh signifikan terhadap tingkat proporsi dana tabarru'.

Penulis menyadari bahwa penelitian ini masih banyak kekurangan dan masih jauh dari kesempurnaan. Adapun keterbatasan dalam penelitian ini antara lain : Pertama, determinan yang dipilih berdasarkan penelitian 
terdahulu terkait defisi beban operasional meliputi biaya komisi, beban pemasaran, beban administrasi dan umum, serta beban lainnya yang terkait, diambil dari total beban operasional yang disajikan dalam laporan laba rugi perusahaan tanpa pemisahan kelompok akun.Kedua,penetapan data unblanced panel pada penelitian ini disebabkan oleh pengumpulan data laporan keuangan yang tidak tersedia secara lengkap pada website masingmasing perusahaan dan adanya tahapan proses yang harus dilalui demi mendapatkan penyempurnaan data dari Otoritas Jasa Keuangan.

Terdapat beberapa saran yang diajukan bagi penelitian selanjutnya, yaitu:Pertama, penelitian lanjutan disarankan untuk mencari alternatif pengukuran yang lebih representatif yang secara teoritis dapat digunakan, misalnya dengan analisis faktor dengan sumber data secara primer. Penggunaan pengukuran yang berbeda terhadap variabel yang ingin diuji dimungkinkan akan menghasilkan temuan yang berbeda sehingga dapat menambah khazanah penelitian.Kedua, menambah objek penelitian tidak terbatas pada Perusahaan Asuransi Jiwa Syariah, akan tetapi mencakup seluruh industri perasuransian syariah dengan rentang waktu yang lebih panjang. Sehingga, output yang dihasilkan diharapkan dapat secara tepat mencerminkan keadaan yang sesungguhnya dari nilai proporsi danatabarru' pada industri asuransi syariah.

\section{DAFTAR PUSTAKA}

Affandi, F. (2016). Analisis Pengaruh Tingkat Inflasi, Nilai Tukar, BI-Rate dan Suku Bunga Bank Konvensional Terhadap Margin Bagi Hasil Deposito Mudarabah Perbankan Syariah di Indonesia Periode 20102015. At-Tawassuth, 1(1), 45-72.

Arfiani, L. R., \& Mulazid, A. S. (2017). Analisis Faktor-Faktor yang Mempengaruhi Tingkat Bagi Hasil Simpanan Mudharabah pada Bank Umum Syariah Indonesia Studi Kasus pada Bank Umum Syariah di Indonesia Periode 2011-2015. Jurnal Ekonomi Dan Perbankan Syariah, 4(1), 1-23.

Arif, M. N. R. Al. (2011). The Effect of Macroeconomics Variable to the Profit Sharing Yield Decision in Indonesia Islamic Banking Industry. Economic Journal of Emerging Markets, Faculty of Economic Universitas Islam Indonesia, 3(3), 235-244.

Badan Pengawas Pasar Modal dan Lembaga Keuangan. (2011). Peraturan Ketua Bapepam-LK No. PER-06/BL/2011 tentang Bentuk dan Susunan Laporan serta Pengumuman Laporan Usaha Asuransi dan Usaha Reasuransi dengan Prinsip Syariah. Jakarta: Bapepam-LK.

Bank Indonesia. (2018). Penjelasan BI Rate sebagai Suku Bunga Acuan. Retrieved from https://www.bi.go.id/id/moneter/birate/penjelasan/Contents/Default.aspx 
Bayinah, A. N., Mardian, S., Mulyati, S., \& Maulidha, E. (2017). Akuntansi Asuransi Syariah (1st ed.). Jakarta: Salemba Empat.

Dewan Standar Akuntansi Keuangan Ikatan Akuntan Indonesia. (2016). Pernyataan Standar Akuntansi Keuangan (PSAK) No. 108 tentang Akuntansi Transaksi Asuransi Syariah, per efektif 1 Januari 2017. Jakarta: Ikatan Akuntan Indonesia.

Dewan Syariah Nasional MUI. (2001). Fatwa DSN-MUI No.21/DSNMUI/X/2001 tentang Pedoman Umum Asuransi Syariah. Jaka: DSN MUI.

Gujarati, D. N., \& Porter, D. C. (2012). Dasar-dasar Ekonometrika. Jakarta: Salemba Empat.

Hamizun bin Ismail. (2013). Observing the Tabarru Rate in a Family Takaful. Proceedings of the 20th National Symposium on Mathematical Sciences, 1152-1158. https://doi.org/10.1063/1.4801261

Harahap, S. S. (2008). Kerangka Teori dan Tujuan Akuntansi Syariah. Jakarta: Pustaka Quantum.

Hidayat, A., \& Rahman, F. (2015). Analisis Faktor-Faktor Yang Dipertimbangkan Dalam Penentuan Nisbah Bagi Hasil Atas Pembiayaan Mudharabah Pada Perbankan Syariah (Studi Empiris Pada Perbankan Syariah Kota Samarinda). Jurnal Ekonomi Dan Bisnis Islam Al-Tijary, 1(1), 73-82.

Ifham, A. (2015). Ini Lho Bank Syariah-Memahami Bank Syariah dengan Mudah (1st ed.). Jakarta: PT Gramedia Pustaka Utama.

K, A. I., \& Sunaryo, K. (2012). Analisis Pengaruh Return on Asset, BOPO, dan Suku Bunga Terhadap Tingkat Bagi Hasil Deposito Mudharabah Pada Bank Umum Syariah. Jurnal Ekonomi Dan Bisnis, 11(1), 29-42.

Karim Consulting Indonesia. (2016). Islamic Insurance Outlook 2017. Jakarta. Retrieved from www.karimcosulting.com

Kuncoro, M. (2013). Metode Riset Untuk Bisnis Dan Ekonomi: Bagaimana Meneliti Dan Menulis Tesis. Jakarta: Erlanga.

Otoritas Jasa Keuangan. (2015). Peraturan Otoritas Jasa Keuangan Nomor 14/POJK.05/2015 Tentang Retensi Sendiri dan Dukungan Reasuransi dalam Negeri. Jakarta.

Otoritas Jasa Keuangan. (2017a). Laporan Perkembangan Keuangan Syariah 2016. Jakarta. Retrieved from www.ojk.go.id

Otoritas Jasa Keuangan. (2017b). Statistik IKNB Syariah. Jakarta. Retrieved from www.ojk.go.id

Purwocaroko, B., \& Suprayogi, N. (2016). Analisis Komposisi Ideal Dana Tabarru - Ujrah Metode Dynamic Financial Analysis Perusahaan 
Asuransi Jiwa Syariah di Indonesia. Jurnal Ekonomi Syariah Teori Dan Terapan, 3(2), 158-172.

Puspitasari, N. (2011). Analisis Keuangan Dinamis pada Manajemen Keuangan Bisnis Asuransi Umum Syariah. Jurnal Manajemen Teknologi, 10(2), 127-144.

Puspitasari, N. (2012). Model Proporsi Tabarru dan Ujrah pada Bisnis Asuransi Umum Syariah di Indonesia. Jurnal Akuntansi Dan Keuangan Indonesia, 9(1), 43-55.

Puspitasari, N. (2016). Determinan Proporsi Dana Tabarru pada Lembaga Keuangan Asuransi Umum Syariah. Jurnal Akuntansi Dan Keuangan Indonesia, 13(2), 160-173.

Republika. (2017). Pangsa Pasar Asuransi Syariah Berpotensi Tembus 5 Persen. Retrieved September 7, 2017, from http://www.republika.co.id/berita/ekonomi/syariahekonomi/17/07/19/otaxnj383-pangsa-pasar-asuransi-syariahberpotensi-tembus-5-persen

Romansyah, D. (2009). Penentuan Rate Bagi Hasil Deposito Mudharabah Bank Syariah di Indonesia: Analisis Teori dan Praktik. Paramadina.

Sarwono, J. (2016). Prosedur-prosedur Analisis Populer Aplikasi Riset Skripsi dan Tesis dengan EViews. Yogyakarta: Gava Media.

Sugiyono. (2008). Metode Penelitian Kuantitatif Kualitatif Dan $R \& D$. Bandung: Alfabeta.

Sula, M. S. (2004). Asuransi Syariah (Life and General): Konsep dan Operasional. Jakarta: Gema Insani Press.

Suseno, \& Astiyah, S. (2009). Inflasi. In Buku Seri Kebanksentralan. Jakarta: Bank Indonesia.

Syarifuddin, D. F. (2015). Konsep, Dinamika dan Respon Kebijakan Nilai Tukar di Indonesia. In Buku Seri Kebanksentralan. Indonesia: Bank Indonesia.

Widarjono, A. (2016). Ekonometrika Pengantar dan Aplikasinya Disertai Panduan Eviews (keempat). Yogyakarta: UPP STIM YKPN.

Yuksel, S., Canoz, I., \& Ozsari, M. (2017). Causality Relationship between Interest Rate of Deposit Banks and Profit Share Rate of Islamic Banks in Turkey. Econworld, 25-27(January), 1-15. Retrieved from https://www.researchgate.net/publication/312972183\%0ACausality 